\title{
English Approximant Consonants: Pronunciation Difficulties Encountered by EFL Students
}

\author{
Uyunnasirah Hambali(1), Ummi Khaerati Syam $^{(2)}$, Muhammad Reza ${ }^{(3)}$ \\ Universitas Muhammadiyah Makassar, Indonesia \\ E-mail: (1)uyunhambali@unismuh.ac.id, ${ }^{(2)}$ ummikhaeratisyam@unismuh.ac.id, \\ (3)muhrezz27@gmail.com
}

Received: 31 October 2021; Revised: 26 November 2021; Accepted: 28 November 2021

\begin{abstract}
The objective that the researchers wish to find out the dominant errors made by the students in pronouncing the words containing English Fricative and Approximant consonants. This research applied quantitative research. Quantitative is basically framed in term of using numbers, closed-end question. Quantitative research is characterized as an efficient examination of wonders by gathering quantifiable information and performing factual, scientific, or computational procedures. In collecting data, the researcher used pronunciation test as instrument in order to get the data. The items of pronunciation test consisted of a list of 120 words. Each sound consisted of 5 words. Pronunciation test was given to the respondents through asking them to pronounce the words clearly and correctly while the researcher was recorded. The result of the research data showed that the students made 1085 or $93.53 \%$ errors of substitution, 38 or $3.28 \%$ errors of omission, and 37 or $3.19 \%$ errors of addition from the total errors found. It indicated that most of the students made errors in substitution with high percentage than omission and errors of substitution had higher percentage than omission and addition. The result of the data analysis showed that there were 179 or $97.28 \%$ errors of substitution, 5 or $2.72 \%$ errors of omission, and there were no errors of addition found in pronouncing English approximant consonants. So, from all kinds of errors, most of the students made errors in substitution both fricative and approximant consonants.
\end{abstract}

Keywords: English Pronunciation; English Approximant Consonants; EFL students

\section{Introduction}

English plays an important role for specific function. Because of the importance of English, we have to give special attention to the English teaching learning in our country. In Indonesia, English has been chosen as the firstforeign language in school curriculum. It is because of a simple reason that English plays an important role in the international world. Our government hopes that it can be a means function to acquire science and technology. Therefore, Indonesian people will become intellectual and skillful person who are ready to face both national and international development.

In English language teaching, there are four language elements. The four skills of language teaching are Listening, Speaking, Reading, and Writing. (Ramadan, 2019). One of them should be noticed is pronunciation is considered difficult element method that can be applied in learning pronunciation.

In line with Pardede (2017) explains that pronunciation plays an important role in learning at the second or a foreign language. Although students have English subject at school, most of them often make mistake, for example: in listening, speaking, reading, and writing. The writer explain previously that language has three major components including phonology, vocabulary, and grammar. Among these components, phonology takes an important role. Automatically, phonology related with pronunciation.

Error analysis is an invaluable source of information to teachers. It provides information on students' errors which in turn helps teachers to correct students' errors and also improves the 
effectiveness of their teaching. According to Richards et al., as cited in Irianto (2018) states that error analysis has been conducted to identify strategies which learners use in language learning, to track the causes of learner's errors, obtain information on common difficulties in language learning or on how to prepare teaching materials.

Based on the observation which is done by the researcher, he found some students' Problems in Pronunciation in terms of English sound, the students having many problems in pronouncing the words, it is because lack of practicing the words.it is proven by some interviews that had been asked to some students. They, the students, are difficult to differentiate the consonant sound for example Plosive, Fricative, approximant and ect.

Based on the background above, problem statement of this research are :

1. What kinds of errors are made by the students in pronouncing the English Fricative Consonants?

2. What kinds of errors are made by the students in pronouncing the English Approximant Consonants?

As the problem statement above, the objective that the researchers wish to find out the dominant errors made by the students in pronouncing the words containing English Fricative and Approximant consonants. The results of this research would be expected to be useful information for many people in learning process, such as: 1) For the teachers, this research is expected to add information and valuable source about pronunciation and to encourage their teaching, especially for teaching English. 2) For the students and the learners, this research is expected to increase the students and the learners' achievement in learning English. 3) For the next research, this research is expected to give information or contribution to other research especially in descriptive research.

The scope of this research was limited to the Errors of English Fricative Consonant

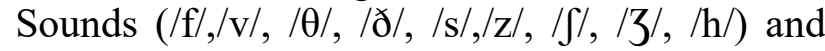
Approximant Consonant Sounds (/w/, /y/, /r/) made by the First Year Students of English Department

\section{Materials and Method}

This research applied quantitative research. quantitative is basically framed in term of using numbers, closed-end question. Quantitative research is characterized as an efficient examination of wonders by gathering quantifiable information and performing factual, scientific, or computational procedures. Quantitative inquire about collects data from existing and potential clients utilizing inspecting strategies and sending out online studies, online surveys, surveys, etc., the comes about of which can be portrayed within the frame of numerical. This research also used numbers, percentage as the result, typically characteristic of quantitative method. This was needed to provide complete research and valid finding result.

In collecting data the researcher used pronunciation test as instrument in order to get the data. The items of pronunciation test consisted of a list of 120 words. Each sound consisted of 5 words. Pronunciation test was given to the respondents through asking them to pronounce the words clearly and correctly while the researcher was recorded.

The researcher used some stages in collecting the data, it could been seen as follows: 1) The researcher used pronunciation test to find out the errors that makes by the students in pronouncing English Errors of English Fricatives and approximant Consonant Sounds make by the First Year Students of English Department. 2) The students' pronunciation was recorded by the researcher, 3) Then convert into written form or transcribe the audio, and 4) Analysis the data.

The researcher analyzed the students' pronunciation in consonant especially fricative sounds and Approximant Consonant Sound. In analyzing data for descriptive research, this research was an error analysis so that the researcher used Non Statistical Approaches/Techniques.

The steps of an error analysis in pronunciation were: 1) The researcher identified the error; 2) The researcher gave the description of the errors; 3) The researcher explained the error which made by the students;

Besides, the researcher also wanted to know the students in pronouncing English consonant in term of fricative and approximant consonants make the dominant errors. From the result of each of the analyses, the researcher was able to identify the significant things related to the errors they made in pronouncing the English fricative and approximant consonants.

\section{Result And Discussion}

In this descriptive research, the researcher 
Table 1. The Kinds of Error in English Fricative Consonants

\begin{tabular}{|c|c|c|c|c|}
\hline No. & \multirow{2}{*}{$\begin{array}{c}\text { Fricative } \\
\text { Conso- } \\
\text { nants }\end{array}$} & \multicolumn{3}{|c|}{ Kinds of Error } \\
\cline { 3 - 5 } & & $\begin{array}{c}\text { Substitu- } \\
\text { tion }\end{array}$ & $\begin{array}{c}\text { Omis- } \\
\text { sion }\end{array}$ & Addition \\
\hline 1. & $/ \mathrm{f} /$ & 65 & 8 & 16 \\
\hline 2. & $/ \mathrm{v} /$ & 59 & - & - \\
\hline 3. & $/ \theta /$ & 132 & 30 & 3 \\
\hline 4. & $/ ð /$ & 238 & - & - \\
\hline 5. & $/ \mathrm{s} /$ & 25 & - & 3 \\
\hline 6. & $/ \mathrm{z} /$ & 198 & - & - \\
\hline 7. & $/ \mathrm{J} /$ & 109 & - & - \\
\hline 8. & $/ 3 /$ & 113 & - & 15 \\
\hline 9. & $/ \mathrm{h} /$ & 146 & - & - \\
\hline & Total & 1085 & 38 & 37 \\
\cline { 3 - 5 } & & & 1160 & \\
\hline Percentage (\%) & $\mathbf{9 3 . 5 3}$ & $\mathbf{3 . 2 8}$ & $\mathbf{3 . 1 9}$ \\
\hline
\end{tabular}

Table 2. The Kinds Error in English Approximant Consonants

\begin{tabular}{|l|l|l|l|l|}
\hline No & $\begin{array}{l}\text { Approx- } \\
\text { imant } \\
\text { Conso- } \\
\text { nants }\end{array}$ & \multicolumn{3}{|c|}{ Kinds of Error } \\
\cline { 3 - 5 } & Substitution & Omission & $\begin{array}{l}\text { Addi- } \\
\text { tion }\end{array}$ \\
\hline 1. & $/ \mathrm{w} /$ & 14 & - & - \\
\hline 2. & $/ \mathrm{r} /$ & 61 & 4 & - \\
\hline 3. & $/ \mathrm{j} /$ & 104 & 1 & - \\
\hline Total & 179 & 5 & - \\
\cline { 3 - 6 } & & \multicolumn{2}{|c|}{184} & - \\
\hline \multicolumn{2}{|l|}{ Percentage } & $\mathbf{9 7 . 2 8}$ & $\mathbf{2 . 7 2}$ & \\
\hline
\end{tabular}

found many errors in the use of English consonants especially fricative and approximant consonants. The researcher identified the errors that the students made in the appendix 2.

The kinds of error in pronouncing the English fricative consonants

Table 1 shows the kinds error which made by the students in pronouncing the english fricative consonants. Based on the table the research- er devided the errors into 3 kinds; substitution, omission, and addition. Each kind contains the error frequency from all students.

Table 1 shows the kinds of error in pronouncing the fricative consonants. There were $\mathbf{1 0 8 5}$ or $93.53 \%$ errors of substitution, 38 or $\mathbf{3 . 2 8 \%}$ errors of omission, and 37 or $\mathbf{3 . 1 9 \%}$ errors of addition from the total errors found.

\section{The Kinds of Error in Pronouncing the Eng- lish Approximant Consonants}

Table 2 shows the kinds error which made by the students in pronouncing the English fricative consonants. Based on the table the researcher divided the errors into 3 kinds; substitution, omission, and addition. Each kind contains the error frequency from all students. Table 2 shows the kinds of error in pronouncing the approximant consonants. There were 179 or $97.28 \%$ errors of substitution, 5 or $2.72 \%$ errors of omission, and there were no errors of addition found in pronouncing English approximant consonants.

Table 3 shows all error made by the students. There were $89(7.69 \%)$ in /f/ sound, $59(5.10 \%)$ in $/ \mathrm{v} /$ sound, $165(14.26 \%)$ in $/ \theta /$ sound, 238 $(20.57 \%)$ in $/ \delta /$ sound, $25(2.16 \%)$ in $/ \mathrm{s} /$ sound, $198(17.11)$ in $/ z /$ sound, $109(9.42 \%)$ in $/ J /$ sound, $128(11.06 \%)$ in $/ 3 /$ sound, $146(12.62 \%)$ in $/ \mathrm{h} /$ sound.

Table 4 shows all error made by the students. There were $14(7.61 \%)$ in $/ \mathrm{w} /$ sound, 65 $(35.33 \%)$ in $/ r /$ sound, and $105(57.06 \%)$ in $/ j /$ sound.

Table 5 shows that there were some students made errors from the words given. Each student made error frequency which has been counted in the table. And each student had their own percentage of error. The result of this descriptive research dialed with the answer of the problem statements which aimed to know about the dominant errors in pronouncing English fricative and

Table 3. Total Error in Fricative Consonant Sounds

\begin{tabular}{|c|l|l|l|l|l|l|l|l|l|}
\hline \multirow{2}{*}{55 Sample } & \multicolumn{70}{|c|}{ Fricative Consonant Sounds } \\
\cline { 2 - 10 } & $/ \mathbf{f} /$ & $/ \mathbf{v} /$ & $/ \mathbf{\theta} /$ & $/ \mathbf{d} /$ & $/ \mathbf{s} /$ & $/ \mathbf{z} /$ & $/ / /$ & $/ / /$ & $/ \mathbf{h} /$ \\
\hline Total Error & 89 & 59 & 165 & 238 & 25 & 198 & 109 & 128 & 146 \\
\hline $\begin{array}{r}\text { Percentage } \\
(\%)\end{array}$ & 7.69 & 5.10 & 14.26 & 20.57 & 2.16 & 17.11 & 9.42 & 11.06 & 12.62 \\
\hline
\end{tabular}


Journal Of Development Research, 5 (2), November 2021, Pages 156-163

Table 4. Total Error in Approximant Consonant Sounds

\begin{tabular}{|c|c|c|c|}
\hline \multirow{2}{*}{55 Sample } & \multicolumn{3}{|c|}{ Approximant Consonant Sounds } \\
\cline { 2 - 4 } & $/ \mathrm{w} /$ & $/ \mathrm{r} /$ & $1 \mathrm{j} /$ \\
\hline Total Error & 14 & 65 & 105 \\
\hline Percentage (\%) & 7.61 & $\mathbf{3 5 . 3 3}$ & 57.06 \\
\hline
\end{tabular}

Table 5. The proportion of error frequency made by the students

\begin{tabular}{|c|c|c|c|}
\hline Number of words & Number of errors & Frequency & Percentage (\%) \\
\hline 60 & 11 & 1 & 20.00 \\
\hline 60 & 12 & 2 & 21.82 \\
\hline 60 & 13 & 2 & 23.64 \\
\hline 60 & 16 & 1 & 29.09 \\
\hline 60 & 18 & 2 & 32.73 \\
\hline 60 & 19 & 2 & 34.55 \\
\hline 60 & 20 & 2 & 36.36 \\
\hline 60 & 21 & 5 & 38.18 \\
\hline 60 & 22 & 2 & 40.00 \\
\hline 60 & 23 & 2 & 41.82 \\
\hline 60 & 24 & 1 & 43.64 \\
\hline 60 & 25 & 9 & 45.45 \\
\hline 60 & 26 & 8 & 47.27 \\
\hline 60 & 27 & 1 & 49.09 \\
\hline 60 & 28 & 4 & 50.90 \\
\hline 60 & 29 & 4 & 52.72 \\
\hline 60 & 30 & 1 & 54.54 \\
\hline 60 & 32 & 1 & 58.18 \\
\hline 60 & 34 & 1 & 61.81 \\
\hline 60 & 36 & 3 & 65.45 \\
\hline 60 & 39 & 1 & 70.90 \\
\hline
\end{tabular}

approximant consonant sounds. The data of errors in pronunciation consisted of fricative consonants and approximant consonant sounds.

The kinds of error in pronouncing the English fricative consonants.

There were 3 kinds of errors in pronouncing the English fricative consonants, substitution, omission, and addition. 1) Substitution is one of the kinds of errors deals with substitution of one sound with another sound. There were some students substitute the sound of some words with incorrect sound. Based on the findings of this research there were 1085 or $93.53 \%$ errors of substitution, 38 or $3.28 \%$ errors of omission, and 37 or $3.19 \%$ errors of addition from the total errors found. As the explanation in findings, every student made errors when pronouncing the fricative sounds. Most of them substitute the word with the near one. As can be seen in the phonetic transcription the students mostly did substitution in pronouncing the fricative consonants. Table 6 is examples of substitution. 2) Omission is one of the kinds of errors which 
Journal Of Development Research, 5 (2), November 2021, Pages 156-163

Table 6. Examples of subtitution

\begin{tabular}{|l|l|l|l|}
\hline Word & Error Identification & Error Description & Error correction \\
\hline Fast & $/ \mathrm{fes} / *$ & $\begin{array}{l}\text { Substitution of vowel /a:/ with / } \\
\text { e/ }\end{array}$ & $/ \mathrm{fa}: \mathrm{st} /$ \\
\hline Cloth & $/ \mathrm{klnt} / *$ & $\begin{array}{l}\text { Substitution of consonant } / \theta / \\
\text { with } / \mathrm{t} / \text { in final position }\end{array}$ & $/ \mathrm{klp} \theta /$ \\
\hline
\end{tabular}

Table 7. Examples of omission

\begin{tabular}{|l|l|l|l|}
\hline Word & Error Identification & Error Description & Error correction \\
\hline Thnk & $/ \theta \mathrm{rn} / *$ & Omission of consonant $/ \mathrm{k} /$ & $/ \theta \mathrm{r} \mathrm{k} /$ \\
\hline Parent & $/$ 'peə.rən/* & $\begin{array}{l}\text { Omission of consonant /t/ in } \\
\text { final position }\end{array}$ & $/$ peə.rənt/ \\
\hline
\end{tabular}

Table 8. Examples of addition

\begin{tabular}{|c|c|c|c|}
\hline Word & Error Identification & Error Description & Error correction \\
\hline Peace & $/ \mathrm{pi}: \mathrm{ys} /{ }^{*}$ & $\begin{array}{c}\text { Addition consonant } / \mathrm{y} / \text { in } \\
\text { middle position }\end{array}$ & $/ \mathrm{pi} \mathrm{s} /$ \\
\hline Cloth & $/ \mathrm{klpwt} / *$ & $\begin{array}{c}\text { Addition consonant } / \mathrm{w} / \text { in } \\
\text { middle position }\end{array}$ & $/ \mathrm{klp} \theta /$ \\
\hline
\end{tabular}

Table 9. Examples of substitution

\begin{tabular}{|l|l|l|l|}
\hline Word & Error Identification & Error Description & Error correction \\
\hline Swim & /swin/* & $\begin{array}{l}\text { Substitution of consonant } / \mathrm{m} / \\
\text { with /n/ in final position }\end{array}$ & $/ \mathrm{sw}$ Im/ \\
\hline Hour & $/$ ovər/* & $\begin{array}{l}\text { Substitution of vowel /a/ with / } \\
\text { o/ in initial position }\end{array}$ & /avə r / \\
\hline
\end{tabular}

Table 10. Examples of omission

\begin{tabular}{|l|l|l|l|}
\hline Word & Error Identification & Error Description & Error correction \\
\hline Yourself & /jo: 'sef/ & Omission of consonant /l/ & /jo: 'self/ \\
\hline Parent & $/$ 'peə.rən/* & $\begin{array}{l}\text { Omission of consonant /t/ in } \\
\text { final position }\end{array}$ & $/$ peə.rənt/ \\
\hline
\end{tabular}

deals with removing the sound of one word. There were some students remove the sound from one word when they pronounce the words. Table 7 is the examples. 3) Addition is the kinds of error which deals with adding some sounds to the correct sound of words. There were some students give addition to the sound of the word when they pronounce it. Table 8 is the examples.

\section{The kinds of error in pronouncing the English Approximant consonants}

Based on the result of data analysis the kinds of students' error in pronouncing the English approximant consonant were substitution and omission. In approximant consonant there were no students did addition. The result of data analysis show that there were 179 or $97.28 \%$ errors of substitution, 5 or $2.72 \%$ errors of omission, and there were no errors of addition found in pronouncing english approximant consonants.

\section{Substitution}

Most student made error by substitute some word with another word, Table 9 is the examples.

\section{Omission}

In pronouncing approximant consonant sounds some student made error and did omission. Table 10 is the examples.

From all kinds of error, the kind of error that students mostly did is substitution error. 
They subtitute the sound of some words with incorrect sound. Substitution occurs when the students change the consonant with the other similar consonant. This is happened because there are several consonants in English which almost has the same utterances. This is then mostly causing them made error in pronouncing the English sounds. They also made errors in omission and addition, but from the result of the data analysis substitution had high percentage than the others.

\section{Conclusion}

Based on the findings and discussions in the previous chapter, the researcher drew the conclusions that based on the analysis of the test, it is proven that the students made 1085 or $93.53 \%$ errors of substitution, 38 or $3.28 \%$ errors of omission, and 37 or $3.19 \%$ errors of addition from the total errors found. It indicated that most of the students made errors in substitution with high percentage than omission. The findings of pronouncing approximant consonants also showed that errors of substitution had higher percentage than omission and addition. The result of the data analysis showed that there were 179 or $97.28 \%$ errors of substitution, 5 or $2.72 \%$ errors of omission, and there were no errors of addition found in pronouncing English approximant consonants. So, from all kinds of errors, most of the students made errors in substitution both fricative and approximant consonants.

\section{References}

Abdullah, H. (2012). An Error Analysis in Simple Present Tense Made By the 8th Year Students of SMPN 1 Malunda. Thesis of Unismuh Makassar

Baker, W. \& Trofimovich, P. (2005) Interaction of native- and second language vowel language vowel system(s) in early and late bilinguals. Language and Speech, 48, 127

Blevins, Juliette. (2006). "New perspectives on English sound patterns: "natural" and "unnatural" in evolutionary phonology", Journal of English Linguistics

Bist R. B. (2014). Research Procedure: an Introduction, Nepal.

Brown, H.D. (2000). Principles of Language Learning and Teaching. New York: Longman

Creswell, John W. (2012). Educational Research: planning, conducting, and evaluating quantitative and qualitative $R e$ search. Fourth Edition. United States of Amrica: Pearson

Depdikbud. (2004). Pedoman Perpustakaan Perguruan Tinggi. Jakarta: Departemen Pendidikan dan Kebudayaan.

Elsa Í Hjøllum and inger M. Mees. (2012). Error Analysis of the Pronunciation of English Consonants by FaroeseSpeaking Learners

Fatemi, Sobhani \& Abolhassani. (2012). Difficulties of Persian Learners of English in Pronouncing some English Consonant Cluster

Fromkin, V., Rodman, R., Hyams, N. (2007).An Introduction to Language (8th ed.). Boston, MA: Thomson Wadsworth

Geoffrey Broughton. (1988). Teaching English as a Foreign Language. Routledge \& Kegan Paul Publisher

Gilakjani, A.P. (2012). A Study of Factors Affecting EFL Learners' English Pronunciation Learning and the Strategies for Instruction, International Journal of Humanities and Social Science, Vol. (2), No. (3), 119-128.

Harmer. (2007). The Practice of English Language Teaching. Longman

Irianto,N,A. (2018). An Analysis of pronunciation Errors of English Consonants : $/ \Theta /$ And $/ Ð /$ By The Students of The English Education Study Program of University of Bengkulu. Journal of English Education and Teaching

Vol.2.No.3.2018.Bengkulu

(JEET)

Lodge, K. (2009). A critical introduction to phonetics New York: Continuum International Publishing Group

Martínez-Celdrán, Eugenio (2004), "Problems in the classification of approximants", Journal of the International Phonetic Association

Naeni Nurwahidah. (2013). An Error Analysis of English Pronunciation Made By Makassar Students. Thesis of Unismuh Makassar

Pardede, H. \& Simarmata, D. (2017). Error Analysis Of Students' Pronunciation in Pronouncing English Vowels And Consonants:The Episteme Journal of Linguistic and Literature Vol 4 No 3.Serdang 
Ramadan. Basic Ideas and Techniques for Teaching the Four Language Skills: Egypt.

iRubric. (2019). Oral Pronunciation Test rubric. Prentice hall: NewYork

Richards. J.C. Plott, J. and Platt H. 1996. Dictionary of Language Teaching and Applied Linguistics London: Longman

Sari, E. M. P. (2015). Interlingual Errors and Intralingual Errors Found In The English Narrative Text Written By Smp, Smk And University Students' In Lampung. School of Teacher Training and Education University of Muhammadiyah, Surakarta

Taher, A. (2011). Error analysis: A study of Swedish junior highschool students' texts andgrammar knowledge,

Tenri A. (2010). English Pronunciation Practice. Universitas Muhammadiyah Makassar

Widyaningtyas, I. (2014). Error Analysis On English Consonants Pronunciation Produced By Second Semester Students: Surabaya-Kediri: Study Program of English Universitas Brawijaya 